\section{The career of William Osler}

\author{
John Launer
}

If you mention the name William Osler to medical students or young doctors, they will almost certainly associate him with "Osler's nodes" - the painful swellings that occur in infective endocarditis, and which he first identified. Much older doctors are likely to know of Osler mainly as the author of the first modern textbook of medicine. His "Principles and Practice of Medicine," first published in 1892, went through seventeen editions and became the model for all subsequent medical textbooks. However, if you could turn the clock back, and ask anyone trained in medicine before the middle of the twentieth century, you would hear a quite different kind of narrative. It might astound you. Sir William Osler was regarded in his own time as quite simply the greatest physician in the history of the world. This view was held widely: among his patients, medical students and colleagues, and by the presidents, prime ministers, archbishops, royalty and world-famous writers he came to look after, and who became his friends. Harvey Cushing, his disciple and first biographer, wrote of him: "Everyone fortunate enough to have been brought in contact with him shared from the beginning in the universal feeling of devotion."1 Herbert Asquith, a British cabinet minister, wrote "He appeared to those of us who met him...to be as perfect as it is given human frailty to be." 2 Osler was considered the paradigm for every doctor. Almost certainly, the teachers of your own teachers will have tried consciously to imitate him.

Osler did not come from a privileged background. His father, originally from Cornwall in England, emigrated to Canada as a young man and was a clergyman in rural Ontario. Osler himself first went to college in Toronto to study classics and divinity, intending to follow his father into the ministry. While there, he became obsessed with natural history and was caught up in the heated debates of the 1860 s concerning the relationship between biblical and scientific truth. As a result, he changed to medicine, and transferred to McGill University in Montreal. By good fortune, he had entered his

Correspondence to Dr John Launer, Professional Development Department, Health Education England, Stewart House, 32 Russell Square, London WC1B 5DN, UK: john.launer@nwl.hee.nhs.uk career at a turning point in western medical education. It was possibly the only historical moment when an educated person could enter medicine with a thorough grounding in classical and Renaissance learning, but then go on to gain an understanding of the new and emerging sciences: biology, zoology, chemistry, physics, anatomy, physiology and pathology. Osler bridged these traditional and modern worlds, and came to personify them both.

\section{FOUNDATIONAL ERA}

A polymath by nature, and highly conscientious, Osler mastered just about every scientific and humanistic subject that he applied himself to. His years in Montreal coincided with the foundational era of clinical medicine. Although he lived in an age before modern therapeutics, he applied all the medical advances of his time: accurate diagnosis, sanitation, attentive nursing, diet and hydration, analgesia and sedation, asepsis, anaesthetics, surgery, and immunisation. By the age of 25 , Osler had become professor of medicine at McGill. From that point in his life, there was scarcely a single aspect of medicine that he did not contribute towards significantly, or initiate himself. These included meticulous clinical history and examination, cultivation of a bedside manner, involvement of physicians in microscopy and post-mortems (he conducted 1000 in Montreal), careful medical record-keeping, bedside teaching, clinical clerkships for medical students and especially postgraduate training. ${ }^{3}$ Perhaps most significantly, he became an advocate of minimalist medicine, emphasising the importance of honesty about the limits of treatment, and avoiding any treatment that had not been shown to work.

McGill was the first of four great medical schools that Osler helped to develop. After ten years in Montreal, he was invited to take up the chair of clinical medicine at the University of Pennsylvania, in Philadelphia. On his departure, fifty Montreal physicians held a dinner in his honour, while his students gave him a gold watch and all escorted him to the station for his journey. Then, following a decade in Philadelphia, he agreed to become chief of staff at Johns Hopkins Hospital in Baltimore - the most expensive and best that the world had ever known. A Harvard professor who attended his farewell dinner on that occasion wrote: "It is extraordinary what a hold he has on the profession in Philadelphia. $\mathrm{He}$ is one of the most popular men I ever knew". 4 In 1904, Osler moved once again, when King Edward the Seventh appointed him as Regius professor of medicine at Oxford. The effect of his departure from America was the same as it had been elsewhere. When his former chief resident, William Thayer, heard of it, he wrote: "I was completely overcome. I could think of nothing else, and, despite myself, I lay on the bed and wept like a child." 5

Osler's role in Oxford had little direct clinical or educational responsibility, but it enabled him to promote innovations in another country and across a continent. He helped to found several new institutions, including the Fellowship of Postgraduate Medicine, publishers of this journal. ${ }^{6}$ In 1911, he was elevated to a baronetcy. Osler carried on writing learned articles - over 750 in his lifetime, many including the first descriptions of significant diseases or syndromes. His passion for book collecting increased, and he gradually built up one of the most important and valuable libraries of medical history in the world. It eventually contained 8000 items, ranging from Assyrian cuneiform tablets to mediaeval manuscripts and the published works of Vesalius and Harvey. He designed its unique catalogue system himself. When he died, he donated the library to McGill. ${ }^{7}$ His ashes and those of his wife remain in a niche among the books, behind a plaque depicting him (figure 1).

\section{GENTLE AND AFFECTIONATE}

One might almost hope that a man like this would have some vices or unattractive qualities such as pomposity, but he seems to have been remarkably kind. He was gentle and affectionate towards all his patients, students and colleagues. He was a doting husband to his wife Grace and father to their only son Revere. More than most of his contemporaries, he supported racial equality, women going to medical school, and internationalism. His social views were surprisingly liberal and he could be outspoken about them. Writing about patent medicines in 1909, he expressed the view: "Treatment of disease is today controlled by big manufacturing pharmacists, who have enslaved us in plausible pseudo-science." ${ }^{8}$ A passionate believer in progress, and the power of science and medicine to improve the human condition, he wrote: "Search the 


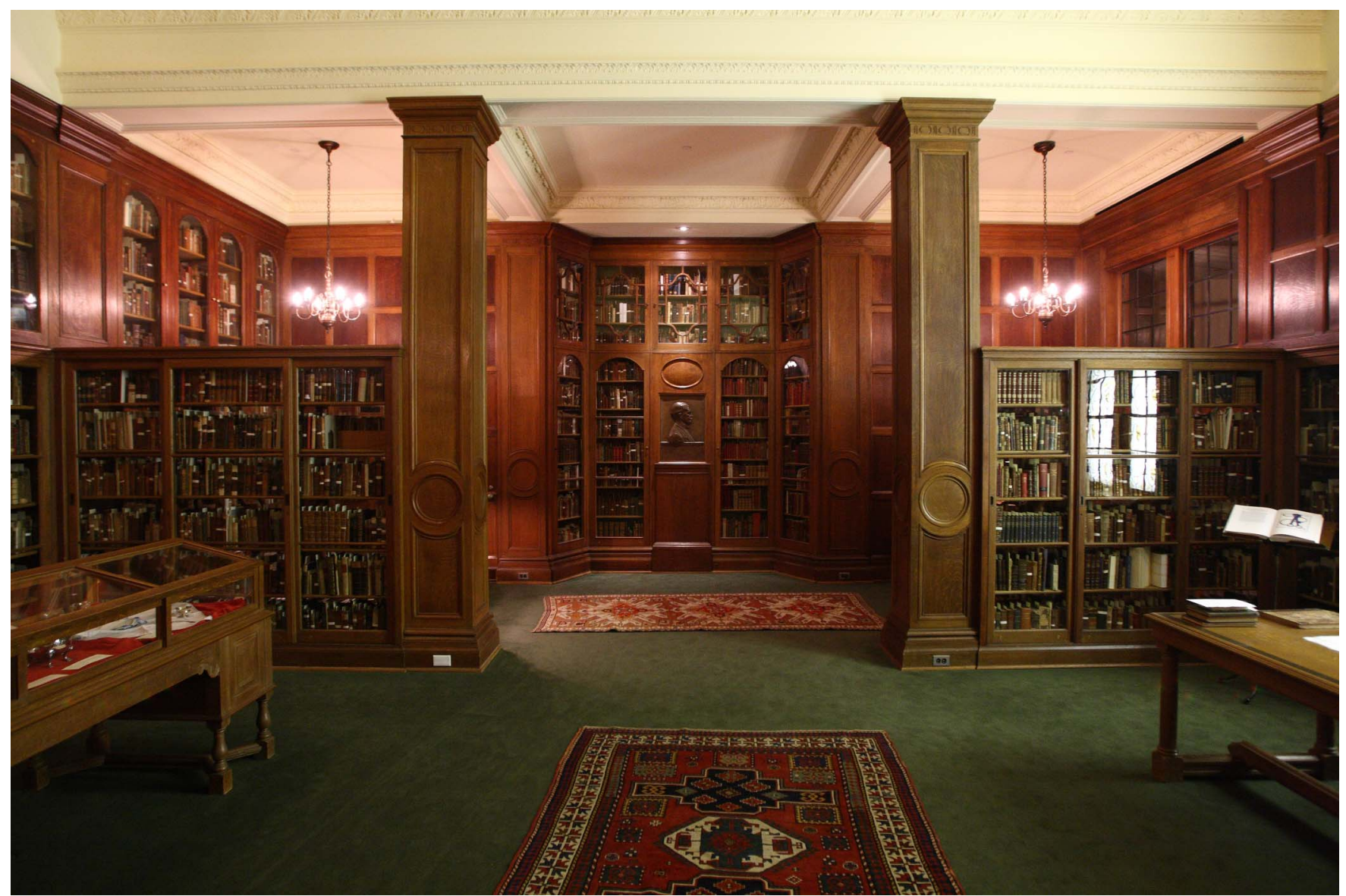

Figure 1 The Osler Library at McGill University, showing the Osler Niche. Credit: Klaus Fiedler, McGill Library and Archives.

scriptures of human achievement, and you cannot find any to equal in beneficence the introduction of sanitation and anaesthesia." ${ }^{9}$ His professional ethics were impeccable: he never criticised his colleagues but modelled instead how to learn from one's own mistakes. ${ }^{10}$ In his biography, the medical historian Michael Bliss has written: "To a modern biographer searching for the feet of clay that make subjects credible, the remarkable unanimity of the sources is disconcerting."11

His presence seems to have helped all his patients feel calmer, and he was especially attuned to children, preferring their company to anyone else's. When he stayed in Edinburgh in his late sixties, his host found him playing bears with a fouryear old in the nursery, with Osler taking the more active and infantile part. $\mathrm{He}$ loved jokes and pranks. When he became a baronet, he designed a coat of arms that prominently included pilchards, to recognise his family's Cornish origins and Revere's love of fishing. After Revere's death in the First World War, Osler's grief was intense, but he found the emotional strength to continue with his own work.
The story of Osler's life and character certainly holds up a mirror to our own time. In spite of all the contemporary emphasis on the importance of leadership in medicine, and training for leadership, it is literally impossible to imagine anyone nowadays conducting a medical career in the way that Osler did - accomplishing his range of achievements, acquiring his untarnished popularity, or leaving behind such an undiminished reputation. However much we may have gained since his death by medical advances he could never have dreamed of, the story of his career draw attentions to some of the personal and collective virtues that medicine has either lost or forgotten. In the words of Michael Bliss "He lived a magnificent, epic, important and more than slightly sainted life."12

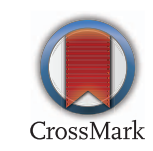

To cite Launer J. Postgrad Med J 2016;92:751-752.

Postgrad Med J 2016;92:751-752.

doi:10.1136/postgradmedj-2016-134618

\section{REFERENCES}

1 Cushing H. William Osler, the man. Annals of Medical History 1919; Summer: 1-42 https://archive. org/details/williamoslerman00cush (accessed 29 Oct 2016).

2 Bliss M. William Osler: A Life in Medicine. Oxford: Oxford University Press, 1999, p.480.

3 Ryan TJ, Osler and his teaching: relevant today. Postgrad Med I 2015;91:540-1.

4 Bliss M. William Osler: A Life in Medicine. Oxford: Oxford University Press, 1999, p.167

5 ibid, p.316.

6 Cook GC. History of the Fellowship of Postgraduate Medicine. Postgrad Med J 2005;81:673.

7 McGill University. The Osler Library. Montreal: McGill University, 1979.

8 Osler W. An address on the treatment of disease. Being the address in medicine before the Ontario Medical Association, Toronto, June $3^{\text {rd }} 1909$. BMJ 1909;2:185-9.

9 Osler W Chauvinism in medicine. Aequanimitas, With Other Addresses to Medical Students, Nurses and Practitioners of Medicine, $2^{\text {nd }}$ ed. Philadelphia PA: Blackiston's, 1925, pp. 277-306.

10 Millard MW. Can Osler teach us about $21^{\text {st }}$ century medical ethics? Proc Bay Univ Med Cent 201;24:237-5.

11 Bliss M. William Osler: A Life in Medicine. Oxford: Oxford University Press, 1999, p.226.

12 ibid, p.xiii. 